\title{
You Will THEREFore UnderSTAND
}

\section{Claudio Magris}

(Trans. Anne Milano Appel) ${ }^{1}$

- To Francesco and Paolo

No, I didn't leave, Director, as you can see, I'm still here. Thank you again for the special permission, truly exceptional, I realize that, don't think I'm not grateful to you. He too was all excited, he never thought he would be granted authorization to enter the Home, when he requested it, so he could come and take me back. Of course he was afraid he hadn't thanked you enough, and in fact someone-I couldn't see who, in this dim light; you can't see very well in here, a shadow slips away before you can make out the face, aside from the fact that they all look alike, we all look alike, it stands to reason, in a place like this_-someone thought he turned back at the last moment to thank you again for your concession and that was why ... The fact that things then turned out the way they did is nobody's fault — or rather, it's my fault, but it doesn't matter who does what in here. At least that's what those outside think: to them we don't matter at all anymore.

To him, however, I did and still do matter, very much so, seeing as he took the trouble to come all the way down here and didn't give up, like the others, faced with the Rest Home's strict regulations prohibiting its guests - for their, for our own sake-from receiving visits that would threaten our peace and tranquility. Not to mention going out, just imagine, that's all we'd need, to find ourselves in that infernal madhouse, that bedlam of traffic and ill-mannered people or worse, not to mention the awful weath$\mathrm{er}$, from which here at least we are sheltered. But he really loves me, he is as much in love as on the first day; he fell head over heels and couldn't be without me. When my health unexpectedly deteriorated and forced me to enter the Rest Home-an attractive, comfortable, well equipped place, no doubt about it - he bawled and ranted and let himself go, not shaving and

1 Claudio Magris, "Lei dunque capirà," (c) Claudio Magris 2006; Garzanti Libri s.p.a., Milan. Used by permission. English translation (c) 2011 by Anne Milano Appel; all rights reserved. 
not even changing his underwear. He bored every friend he met with a long story about his misfortune and how lonely he was. It wasn't enough for him to know that I was close by and well cared for, better there than at home or in the hospital, he would say, that's for sure, but how can I manage all alone, I wander around the empty rooms as if they were someone else's, a stranger's, if I open a drawer it's always the wrong one, I reheat the coffee from the day before, revolting, and the bed, the empty bed ... On her side I can still see the slight depression left by her body, he would say excitedly; it's impossible, I know, the sheets have been changed who knows how many times since then, but it's there, yes, there, he repeated, that slight hollow beside me, with me, her absence by my side, my life's companion, I can't even find my books anymore, it was she who kept them in order, no, you can't possibly understand ...

After a while even his friends avoided him, that persistent melancholy was annoying to people, not to mention the breast-beating, accusing himself of God knows what failings ... It's the accepted thing, they would say, everyone does it, when someone is ill there's nothing else to be done, Rest Homes are there for that purpose, for our loved ones, for their well-being when they are not well, because when they are ill—and God knows I was ill, with that damned infection, fire and ice, the breakdown of my entire body, worse than if I had been bitten by a venomous snake-we don't know how to help them, what to do for them. That's why Rest Homes exist. We have to resign ourselves, indeed be content and at peace with our conscience, when we accompany them there and entrust them to that qualified staff.

But not him, oh no, the heart has its reasons, he would say, the heart breaks, and if you tell it not to break, it breaks just the same, like mine, he mourned, oh, I can't go on, thinking of her there, in that place, in those large wards or tiny cells, in that rabbit warren, surrounded by all those others, shrivelled up like mummies, soiled; I know they clean them up right away, everything is always kept in order, even the garden, but meanwhile she, she who is so beautiful and delicate and dreamy-yes, that's how he sees me, he's truly a darling man, my husband-with that face and that smile untouched by the years, in there with all those others-she may well be comfortable, he added, she doesn't lack for anything, I know, but I, what will I do without her, lucky her, poor me, have mercy, have mercy on this unhappy lover ... If you think I'm exaggerating, he would tell his friends, it means you have no heart and no feelings, you have no poetry in your heart, who can ever understand my pain and torment, my suffering, a poet's grief ... 
And he would start to write, in those notebooks of his that I'm so familiar with; he would write my name and then something else, and again my name and something more, but afterwards he would tear up the sheet and throw it away, because he realized that he couldn't think of anything to say. He knows these things, it's in his blood, he notices immediately if he comes out with something trite-he's always excused anything he did, with women moreover he allowed himself to flit from one to the other whenever he pleased and he also expected to be understood and forgiven, since he was so swayable and susceptible ...-but with words, no, there he excused nothing, he sensed at once when something wasn't right and did not aim to deceive.

In short, only when we were together did he feel entirely serene, confident - even about what he wrote, after he had read it to me and had seen in my eyes - or rather on your mouth, he would say, when my lips, pouting a bit at first, parted slightly, almost a smile, no, not yet, but ...-I would prune his words, of course-excessive, immoderate and magnanimous as he has always been, he lavished words profusely and I pared them for him, discarding the rind, the core and even a lot of the pulp, when it was necessary. He would not have been capable of it, fervent, unrestrained and compulsive as he was, always a morsel and a glass too much, but he let himself be put on a diet by me and he knew that, if something remained on the plate after I had passed everything through the sieve, it was truly something good. With you, he would say, with you at my side I know who I am and I'm not so bad.

If they spoiled him with all those laurels and literary awards, it's thanks to me, since it was I who trimmed away the fat and cleansed his pages of all that sentimental pap-oh, the amount of rubbish that ended up in the wastebasket because of me, it could be that among the scrap paper something exceptional might even have been lost, who knows, well, never mind, serves him right. He, however, not a word-he always agreed with me, he had a nose for these things and he appreciated mine, and when he realized that sometimes I was wrong-oh, hardly ever-he went on not saying a word, he certainly wasn't going to risk fighting over a line or two. I was his Muse and a Muse must be obeyed, right?

A poet faithfully repeats what she dictates and that's how he achieves the laurel. Then he brings it home and his Muse puts it in the roast that she so lovingly prepares for him, because that way it's more savoury. He, confused between the laurel on his head and the one in his plate, would even repeat what I said at home, at the table. Dear God, chatterbox that he is, he would elaborate and magnify, and add his own embellishments and 
I would let him hold forth, especially if there were people there, and in fact I was proud of his way of speaking, so lively and cocky-it's what I miss most in here, everyone silent or whispering like in church-I was proud to hear him repeat, all flowery and exaggerated and overblown, the things that I had told him. Even if he ridiculed them, to impress the company, I let him do it, after all I knew that when it came to the important things, wear your sweater, stop smoking and playing cards with those other lazy bums, don't be such a big spender, stop ranting about politics and don't come home late at night, he didn't say a word, just like when I deleted a page or a chapter or a poem, for instance, all the ones he wrote for that Barbie doll three years ago.

I was proud that everyone admired him and I didn't care whether they knew that it was thanks to me, that I was the one who made him toe the line. And it makes me angry that, now, with the excuse of his pain and torment, he abandons himself to all those transgressions which I had cleaned up one by one, like the threads on his jacket or the hairs in his nose-yes, I dressed him up and changed him from head to toe, from the time we got together, so that no one recognized him anymore; I'm sure that he too, seeing his face in the mirror, all spick and span, was left gaping. It was an exhausting effort, but that pampered man, instead of being grateful ... Never mind, it's a woman's destiny. For one thing ... But now those dirty nails again, stubbly beard, up until all hours then asleep until noon ... he does what he wants, like a good-for-nothing adolescent, always in a mess ... Oh, had I left, it would have taken me just a couple of days ...

I know, I know, sometimes he couldn't stand it any more ... well, and I could? And yet... and yet he too knows that, aside from everything else, it is in his arms that I became a woman and it is in mine that he became a man ... a real man, not a guarded narcissist; a man who stays on the right track and isn't afraid of what will happen to him. To be honest, I've heard that he has become insufferable since I've been in here, snivelling and arrogant; he asks everyone for help and doesn't listen to anybody, and he expects them to listen and admire him just because he doesn't know which way to turn. But if I were there...

Then too, who knows how he'll manage now that I'm no longer there to type his poetry ... I make too many mistakes, he would say, I don't do a good job, it's a disgrace, still it was also convenient, so it fell to me to do it and meanwhile he would read the newspaper or go have a beer. Now, without me, he'll realize-those women who go to hear him, every time he reads something of his in public or gives a lecture, mollycoddle him, fall all over him—those silly geese adore anyone who can make two words rhyme 
and delude themselves that a warm-hearted man must lie under therethey embrace him, drag him here and there, one takes his jacket and another his arm, they make him autograph his books, they write him fanatical letters and he responds to all of them, he too in elated tones. At times he would ask me to respond for him, in his name, and it was amusing to make them all the more ecstatic and keep them on tenterhooks-but I'd like to see if they'd sit at the typewriter or at the computer for him, transcribing his illegible jottings, that neurotic handwriting of his.

Loving and headstrong though, like a true neurotic. It's nice to be loved by a neurotic, it makes you feel secure. You know he won't get over it, an obsession that resists all of life's blows. I don't think I would have fallen so in love with him if he hadn't been so neurotic. You know something about his anxious meticulousness, Director. His application to obtain permission for me to leave, with all the proper stamps and seals, his appeal after your first denial, with new attachments and punctilious objection to your document's formal flaws, always with that masterly dose of bureaucratic precision, maniacal juridical formalism and startling flights of fancy and surges of passion, intended to impress the Rest Home's Board of Trustees - even if they, and especially you, Director, do not allow yourselves to be influenced by fine phrases, supplication and entreaties that would make the dead weep.

You, Director, know the human heart better than anyone else. From time immemorial, an eternity, you've seen it swell up pompously, throb excitedly, open up enthusiastically when it's convenient and dry up like a sponge when it comes to actually paying the piper-always in good faith, for heavens sake, everyone is pleased to suffer for their hypersensitivity and to be agonizingly moved to pity at seeing the suffering of those whom they have innocently injured. How can we help it, that's life; of course it's sad to see them wilt, those flowers that cruel fate has made us trample, but ... - He, too, for that matter, felt no qualms about some innocent, infatuated girl. If he plucked some little flower, he was convinced that, after all, they should be proud to adorn the wreath of a poet, shouldn't they?

What's that? Pardon me, Director, I can't hear you very well. It's that I can't see you, in this darkness-I know, I know, it's not because the Home is miserly, it's that many are sleeping, I didn't mean to complain, that's all we need! I would be quite an ingrate, after being given that extraordinary permission, most extraordinary, a real kindness, the fact that later I didn't take advantage of it is only my own fault. Actually, I like this veiled, opaque light; it makes me feel like I'm at the bottom of the sea, where everything is fixed, motionless, even time. We used to love to descend 
together into the dark blue water, abruptly deep, on the shore of that island of ours; perhaps it was only down there, in the fixity of those instants long as centuries, that we were happy. But then even in here, down here, in this semi-darkness ... Anyway all I meant to say is that I can't see you, Director, I don't know where you are, and so maybe I turn the wrong way and sometimes your words escape me. Oh, you wanted to ask me if he was like that with me as well, if I too was one of those poor little flowers of his, fondled, crushed, and when no longer fresh, tossed aside ...

Not on your life! Not me, don't worry. Besides, otherwise he wouldn't have taken the trouble to come all the way in here, down here; a frightening thing to do, in fact no one else ever felt up to it—only him, because of me, for me because I'm not a flower to be plucked, he said, but a flame to warm the heart or even scorch it, a bittersweet wine that quenched his thirst, yet with each sip left him an intense burning, a scorching heat ... It was I who taught him everything, to stay inside me for a long time, before and after, to wait for me to give him permission, to order him to come, and everything else. When we made love, it was like a sea, a large wave that rocks heaves plunges breaks on the shore; without me he would still be a child, someone who makes love as if he were blowing his nose, not a man.

Yes, it was I who taught him everything. Not only love. That too, of course, but also everything else, courage, faithfulness, facing the dark and ignoring the shivers ...-a man, not a scribbler who swaggers with his pen and then slinks away. He would enter me like a sword, compliant and powerful, master and slave and companion and all the rest-the hawk's wing pierces the sky, smell of damp earth, mine, his, leaves furl up in the wind. With that sword you're no longer afraid of anything and he too, in my arms and between my legs, forgot his fears, which of course he had, but he tossed them behind him, like he did with his clothes when we went to bed. How I pity those who are afraid, people who get worked up over a lump below the breast or in the belly, over a cockroach under the table or a draft; people are full of tics, it means they don't make love right, if they did they'd get over those fixations, I never made such a fuss over that nasty infection though God knows how I despised it, but you can't very well go into hysterics over every snake you come across-even if those thugs dressed in black come and take you and slam you into one of their black cars, all you can do is pity them, like all jailers curmudgeons and overseers in this world. And if I felt a shiver, it's natural, it happens, all I had to do was think of his ...-

Forgive me, Director, I didn't mean to take liberties much less be impolite. They've told me over and over again not to talk about these 
things. With you, especially, it would be an effrontery, an indecency. However ... you see, I too once thought that you were very strict, puritanical, someone who would punish Adam and Eve maybe simply because they made love in that beautiful garden, where just seeing all those beautiful flowers, those open corollas, they must have been overcome by a desire even stronger than ours that summer at the sea shore ... In short, you come across as someone who doesn't approve of co-ed classes. It's a false accusation, I can attest to it, even if you don't give a damn about the lies and improprieties that are said about you. In the time I've been here in this huge house-I haven't even seen it all, not even close, not even a tiny part - this doesn't appear to be so, it doesn't look as if you pay any attention to those things, in fact, it seems to please you when two ... But you don't interfere. Whereas when it comes to other matters, instead-such as fighting, lying, hurting someone-it's immediately clear that you're unyielding, you become a strict disciplinarian. It could also be the fact that there's not too much to do, in here, that causes people to slide a hand up a skirt or in someone's pants ... with these dim lights and the cold and the lack of air we're all a little dispirited, otherwise we wouldn't be here, after all, and it's not as if we have a strong desire to fu ... that is, to experience the pleasures and sins of the flesh. And so you, running the Home, don't pay any attention and allow some harmless promiscuity to go on.

At least I think so, because we've never talked about it. Naturally, since I've never seen you. I was a little surprised at this, I must say. It's obvious that you never allow yourself to be seen out there. Maybe you go for a walk in disguise, undoubtedly in fact, while you're certainly not an inmate like us, you naturally can't take the chance of being recognized. Can you imagine? Everyone crowding around you, petitioning thanking protesting imploring insulting asking forgiveness reproaching bringing up complaints and issues and scrapes and misfortunes from who knows when ... not even you, so authoritative and feared, could wriggle out of it so easily. But here inside, in the Home, there's no reason you couldn't show us your facejust to reassure us, look, I'm here, don't worry. After all, you are the Director of the Foundation that provides for the Home, the first and only Director so far, the one who set up the whole shebang, inside and out, for our sake ... And yet you're never seen in here, who's ever seen you? It might be the fault of those lights, so dim and faint they seem to be out-which perhaps may well be atmospheric, forgive me, and personally I don't mind it, but it's not in good taste, at times it feels like being in a shady discotheque, the kind where you can't understand a thing because of that music going full blast, here everyone is silent or they speak so low that you 
can't understand a thing just the same.

But, apart from the lights, it's not as if there's a great difference between the Home and the outside, the way people think or at least the way the Home advertises in its subsidiaries and branch offices, in its numerous agencies. You can't believe those salesmen; I realize selling the Brooklyn Bridge is their job, they have a family, they show you brochures and photographs and descriptions, spectacular beaches cloudless skies, a ticket to paradise costs little, comfort and reputation assured and discounts for families, when applicable, you'll see, Madam, down there everything is different, the authentic life that our false and corrupt society has polluted. Adam and Eve brought filth everywhere and their children and grandchildren were even worse, the world is sick and broken, get in the car-that too provided by the company, included in the price-and go, you won't regret it, you can't begin to imagine how happy you'll be, that's how different the Home is.

And instead I almost didn't notice that I was somewhere else. The streets, for example, look the same, they're nearly identical. Murky with people walking about, brushing against each other, jostling one another, their looks menacing and suspicious, they disappear between the houses and along the passageways, a river flowing between the bends and curves, that widens and narrows between the banks even though you cannot see the banks, there aren't any. The water sparkles for a moment in the light, disappears in shadow; a cloud, the ceiling lowers, the dark tide hurtles down on you, it overruns you but doesn't harm you, the water is gentle like mist, the crowd that presses against you is also gentle, bodies of soft mud that melt in your hands and vanish before you can embrace them. The current is swift, the trees dip their boughs and branches over the water, they lash your face but it's only a delicate leafy caress that fades at once; a face passes alongside you, smiles at you uncertainly and is already gone in the yielding throng, a figure of smoke. Your heart clenches. My love, shield me ...

That Sunday in the city where you were stationed as a soldier-yesterday, today, a thousand years ago, we're not allowed to have clocks and calendars in here, they confiscate them from us upon entering, everything is now and never-well, a soldier so to speak, you were in uniform, with all those books you had written they quickly assigned you to a desk job, in the administrative office; even if you made a lot of mistakes you didn't care, because they weren't your songs; you like the typewriter for what it is, your fingers on the keys like fate's blows, letters and numbers flowing over the paper. You always liked to write, it didn't matter what, writing, period! it's the act that counts, the act of a poet, the act of a king, sovereign license 
over the lowly consonants and vowels that leap out on command and line up, forward march, right face, disperse ranks. Crumple up the sheet and toss it in the wastebasket; but there, in the barracks, you couldn't do this; each sheet was accurate and exact and you filed it in its proper place among the charts and registers. If only it had always been that way, outside of the barracks as well, once you completed your military service; every word every sentence every page justified and essential like in those registers, a fervent, exquisite song of life.

Instead outside, off duty, without the uniform, out on leave, songs, yours included, get mixed up in the babbling and prattling, all a confused jabbering lost along the way; it's even useless to raise your voice, worse yet, a shrill grandiloquence, a gust scatters the pages on the table and blows them who knows where. Even now that, out there, you scream my name, grief-stricken, or one of those many names that you liked to call me as you climaxed in me, my Eurydice, you would say, my ...- - even now that you are wailing and weeping for your lost love, in rhyme with the gushing of streams and the rustling of leaves or in blank verse as rowdy as the honking of horns in the street, who knows what will come out of it ...

In the barracks, however, you kept the papers in order; even the quartermaster was happy with you and gladly gave you a pass to go on leave when I came to visit you. Like that Sunday ... the streets crowded with people, pushing, shoving, sometimes we got separated in the crowd. The two of us shy eager ashamed looking for a room, to carve out of that universe baring its fangs a tiny niche for ourselves, just for us, so teeny and narrow that we could only lie close together, clasped tightly. Making love on the floor, on the chair near the pitcher of water in that old bawd's room; an hour, she said with obscene familiarity, she knew that noisy life, adult, hostile, threatened our youth-no, those verses aren't yours, my love, perhaps you didn't even know them, it was I who recalled and recited them, amid that crowd, and you never tired of repeating them, you always had a sure instinct for greatness, and you sang and retold them on your lyre. What did it matter if they weren't yours, they were yours, you said; poetry speaks for everyone, even for me who could never create those verses. You knew that poetry is never yours alone, like love, but belongs to everyone; it's not the poet who creates the word, you said and declaimed, it's the word that swoops down on him and makes him a poet, maybe that way you consoled yourself a little, feeble reed into which god, no thanks to you, breathes as in all reeds, even those that are grander and more melodious though not by their own virtue. What does it matter whose song it is if it speaks for you, for us, what does it matter where the water comes from that quench- 
es your thirst and becomes yours in your mouth? Even many of my words ended up in your songs, among your most celebrated verses admired by all, and I'm happy about it, because it's you who recite them and that way you love me even more ...

We climbed quickly up those stairs, not to lose precious minutes and seconds of that hour paid for in advance; I felt pity for that bawd who was smiling contemptuously, poor deluded soul, convinced that those two, we two, like so many others, after a shudder or two and a stain on the sheets would come down those stairs like strangers, indifferent, in a hurry to say goodbye and go our separate ways. Poor deluded old woman; if only it were always that way, cash in her sweaty palm, some quick panting, an illicit trick or two, to each his own, heart undisturbed, at peace, absent, not there and everything is fine, the world is a rooming house, a paradise, no sting to the heart, no goodbyes. But instead, even in the weariest routine, in the most lurid transgression, that stabbing pang of love, those eyes estranged and lost that for a moment express all that's yet to come ... Happiness, emptiness, tragedy, the untenable intensity of remaining together ...

When it became clear that I was about to move into the Home and you spent hours at my bedside, I saw myself so beautiful in your eyes; I was desirable through your gaze; I knew I was white and pale, drained by the poison, but in your eyes I was still tan from the sun and sea like when we would go to that little island of ours, we would swim there and land amidst the shrieking of seagulls, naked and gleaming like gods. You sat on the edge of the bed, I took your hand and made you caress me under the covers; your hand sank into me, the fisherman descended into the grotto once again wet and moist, I guided you into those depths, without fear, I've never been afraid of love, you however were, man of little faith, but each time I pulled you out of the abyss of anxiety making you plunge into me, enter me, penetrate my deep obscurity; when you dove into the dark night of my womb you regained your clarity, your release and your assurance. Like in that grotto of our island, you would say; we dove into the darkness and found ourselves in a breathtaking blue light.

That time too, at first, you were hesitant to plunge into me; your hand was uncertain under the covers, it was mine that guided it and pushed it inside. As you entered me I felt that you were rising up from the depths of your fear, that you were finding strength and courage; your hand cautious at first became bold and forceful, that nocturnal pleasure on the verge of the immense night that was descending upon us was uncontainable, at that hand of yours I came as never before-go to the sea, I said soon afterwards, 
to that bay of ours, so blue that it appears black-after making love, on that island, we would always dive into the sea-go, do it for me too, any pleasure of yours is also mine and it will restore you to me stronger and more a man. Without that time under the covers-the last time, then that poison in my veins won-you perhaps would not have had the courage to come here, to come and look for me down here, in the Home, in this other cavern of darkness.

And so, Director, upon hearing the news of that incredible, one of a kind permission, never before granted to anyone else, the first thing I thought about was going to the sea together again. How persuasive he must have been, I thought proudly, who knows how he managed to move even you, Director, so merciful but also just and severe, you who search people's hearts and certainly do not allow yourself to be fooled by scenes and facile tears, like so many out there, ready to let themselves be duped by anyone who wears his heart on his sleeve. In fact, I must say that if I had known about that foolhardy, insane, grandiose idea of his to come here and appear before you with that unheard-of, brazen request, I would have been afraid that you might get incensed and consider it an act of bravado. I know him, that man of mine, even when he complains about a bellyache it seems like a tragedy. It annoyed me too at times and in fact with me he didn't dare make such scenes, I quickly made him lose his appetite for it. Now instead they tell me that he's raving wildly again ... Nevertheless ... well, few people realize how much genuine pain and passion and love there are in his performances. Of course not, they're not poets, those people, so they can't understand someone who is a poet. But you, Director, must certainly be a poet, obscure and grand, anonymous, like those great ancient poets, seeing as we don't know who they were ... Therefore, if you allowed him to come to take me back, you must have read his heart better than me, because at times I too ...

I quickly followed him; the thought of that sea gave me wings, I walked swiftly, climbing the stairs in the dim light, through long corridors, landings and areas cluttered with bags, suitcases and parcels, all stuff we try to bring in here which, to comply with the rules, however, we are obliged to hand over to the staff. Who knows what they do with them, afterwards, since it is also forbidden to return those bags to the families. Perhaps they simply remain there, abandoned in a corner, left to rot and waste away until they disappear. Otherwise they would have piled up and filled the entire Home a long time ago.

I walked, ran, stumbled into a puddle, I followed him, I chased after him, I couldn't wait to talk to him, to look into his eyes. But it was for- 
bidden and I understood the reasons. If the others had known about that impossible visit, never before granted to anyone ... maybe once, they say, a long time ago, but it's one of those stories that are told to children to make them be good, to make them believe that it's not actually impossible so therefore they shouldn't worry and should be hopeful, but it happened so very, very long ago, so many years ago that it's as if it never happened, or maybe it did but so long ago that we can hope but must be patient, very patient, because before it happens again the same amount of time must pass so there's no point in getting worked up. But if they had known that he had come here, down here, in flesh and blood, for me, if they had seen us together, who knows how they would have stormed and raged. Dear God, raged. They don't, we don't frighten anyone, so gaunt and emaciated, an assortment of clothes hanging on a hook. But there are so many of us - of them, I thought I could now say-countless numbers, that we can be a little frightening, a swarm of insects that darkens the sky.

I ran silently, forcing my way through the frail crowd. A succession of figures passed in front of me, shadows like the people passing by on that seaside promenade, silhouetted against the fiery blaze of sunset, paper dolls folded over by the wind. I made my way through them, breathless, trying not to be too conspicuous, returning a few faint smiles of greeting that I thought I glimpsed every once in a while on someone's face. Mists parted, clumps of mud slid soundlessly under my feet; he ahead of me, in the distance, his back straight and youthful as if the years hadn't passed for him either. Every so often he disappeared around the bend of a passageway, beyond a steep slope, sinking into those strange scarlet flowers that the Administration scatters throughout the Home and then leaves piled up everywhere, an ever more sombre pall of embers. Odd how I didn't smell the undoubtedly strong odour of those fleshy, overblown petals; maybe I got used to it, I thought, as he reappeared, staggering up from a rusty trickle where he had slipped. He struggled on, I merely skimmed along those bogs and crags; I would have caught up with him in an instant had I not held back, I knew that we should not be seen together, assuming those blank eyes around us, having been in the dark so long, could still distinguish one shade from another.

I wasn't frightened by the idea that I would soon find myself outside again, where everything is so much more difficult and ruthless than here in the Home. Alone I would have been afraid and I would never have left this peacefulness which I had yearned and pleaded for when that disease more venomous than a serpent prostrated me. He too, alone out there, had certainly been afraid; maybe that's why he came to take me back. Not to save 
me- - even though he was convinced of it, though his songs led you to believe that. Deceptive maybe, but captivating; I would have followed him just to hear them again.

No, he hadn't come to save me, but to be saved. How could I sing my songs in a foreign land? he would say. I was his lost land, the lymph of his flourishing, of his life. He had come to take back his land, from which he had been exiled. And also to be protected once again from those savage blows that come from all sides, that I had always parried for him, the poisonous arrows meant for him which instead encountered my breast, tender in his hand but resilient as a rounded shield when it came to meeting and stopping those arrows, in intercepting and absorbing their poison before it got to him. In the end there were too many of them and the poison overcame me, but in his arms I too had been happy and fearless; it doesn't matter where the arrow strikes, on one's flank or in the heart, on mine or yours, when two people are one. Without him, I too would have been nothing, like him; a silly little woman and a pipsqueak of a man who look around timidly trying to make a good impression, without seeing the lilies of the fields.

No, I didn't fear the raw, cutting air that would soon blow in my face again. Nor the complications that I would find back home. He must undoubtedly have gotten into some romantic pickle, in my absence, I thought; even a serious one, because he's a magnanimous soul who falls in love for real, or at least he tells himself that and believes it, and so he causes trouble. But I had already forgiven him-what am I saying, forgiven; only those who are not in love can readily forgive, those who love are implacable, they don't let anything slip by. Besides he wouldn't dare con me like he did himself, telling me about the munificent 'sisters' who only wanted to alleviate his great sorrow, and saying that not even he understood how it could sometimes have happened that ... No, I did not forgive him by any means and yes, I ran after him, in part to give him a piece of my mind, to make him pay, I didn't know for what, but in any case to make him pay. I would have liked to see if he had the courage to justify himself - I had cured him of that mania of his of always being right some time ago, as well as that arrogance of always wanting to refute me when I told him off-and I knew very well why, or at least I sensed it, I felt i-his insinuation that I too could be wrong sometimes ... God how that conceited egotism of his offended me, the need to raise his voice too, as if to mimic me, make fun of me, how he exasperated me with those silly notions he had of being buddy-buddy with everybody, of opening the door and his pockets to the first comer, without thinking of his family. But with 
me that doesn't work and after a while he too got his head together.

I wasn't worried about those few silly women who had certainly consoled him during my absence. I couldn't care less about those types; I know that he would be the first to laugh, just comparing them to me, and comparing them to me has always been a mania of his, a real obsession. So much the better for me, that way he dumped them right away, bored nearly before he started. I understand that a husband does these things, although, if I catch him red-handed, I can make him permanently lose the urge to repeat them. He too has always known who's in charge, in bed. Instead that bohemian air, that way of being everybody's buddy that they tell me he's now affected again — of course, poetry, naturally, humanity, the religious sense of human and divine, I know the old story, and meanwhile smoking in bed and forgetting my mother's birthday, while he always remembers that of his old nanny and maybe his female schoolmates, that really used to make me hit the ceiling and I would've liked to see him start in again.

And so I ran after him, making my way through the crowd that surrounded me and scattered like a flock of birds when you shake the branches they've settled in. The way was long, very long-no, not infinite, the Home is enormous but not infinite, as is thought out there, and soon I would cross the channels that surround it, I would take those elevators that go up countless floors, reach the door guarded by those electronic dogs who had received orders from Headquarters to allow us to leave and I would be gone, I'd be out; we could look at each other face to face, his gaze, mine, the years flown away like those nocturnal birds that rose up as I passed by.

It was close, I could feel it; close, so to speak, the Home is immense and its corridors stairs passageways vaults lounges galleries seemed neverending, but I knew, I could feel that soon-it didn't matter when, years or moments-I would be out and I would be in his arms, his lips on mine, his hands on my quiescent breasts, on my forgetful sex that was beginning to remember, to reawaken, a trickle of moisture sprang again from the parched fountainhead. At night I seemed to feel his hand in mine, like always, in the limpid, deep waters of sleep, so different from these murky, gurgling swamps that won't let us sleep-the Home is the province of insomnia, as soon as one of us falls asleep-though it almost never happens - the watchman on duty immediately shakes him. They say that, given the poor condition we're in, sleeping is bad for us and we mustn't let ourselves drift off, it's dangerous, like falling asleep in the snow.

But on the contrary, we here would like to sleep, and I was happy 
because I would soon be able to sleep, sleep with him-make love in bed, on the floor and then remain close together, in each other's arms, intertwined, once we laughed so hard because he kissed my foot and I thought I was kissing his shoulder and instead, in that tangle of legs and arms, it was my own. To fall asleep together again, with him still inside me, I could still feel him throb, less and less, as we slipped into sleep, love is this sleep in which it continues and gently fades without ever really fading - otherwise it's only a twitch, a friction, a tremor and afterwards you just feel like getting up, putting your clothes back on and going off on your own. I'm sure that's what he did with all the others, that only in me did he sleep with such great abandon.

His lips, his mouth, his words. So many things to say to one another, to tell each other, after such a long time. I thought I could hear him already, when he gets going he never stops, he talks and talks, even in bed, sometimes I'd rather he shut up a little, at least in bed. Among other things, I had decided to tell him that I wanted separate rooms, because he snores and because sometimes you need to be alone. And anyway, might as well go whole hog; since he came all the way down here-some nerve and some courage, that's why I like him so much, there's no one capable of such reckless acts as him- he might as well exert himself a little more and buy me a more decent apartment, up there, larger, centrally located, with a garage- to eliminate all that trouble of looking for a parking spot each time, a job that falls to me, because otherwise he ends up bumping some car-and with a nice view. After all, if he wants to, he can make a little money if he rolls up his sleeves and sits down at the desk without being so finicky about what they ask him to write, instead of spending his life talking, ranting and raving all day. That way of speaking he has ... However even talking, at times, is making love and I couldn't wait to hear him, to know what he had done and said and written, if he had composed any new songs.

And above all what had happened to that unfinished song, never really even started, it gnawed at his heart that he wasn't able to begin singing it. That was everything, he said; to sing it and then set down his lyre, no longer needed, once his song had thrown open the mysterious doors and revealed the secret. Behind there, he would say, showing me the impenetrable doors of the Rest Home when we glimpsed them from afar as we strolled around the outskirts of the city, you can see things as they are. Here outside all we can see are those doors, whose gleaming convex laminae reflect splintered images of things that lengthen obliquely or inflate and swell if we move backward or forward a little, growing thinner, expanding, 
shrinking. All we know are those ephemeral travesties, not the truth that lies hidden on the other side, behind those bronze mirrors. But I, my love, he would say to me, can no longer celebrate only the mirages of those mirrors, those illusory reflections. My song must be about reality, truth, that which holds the world together or dissolves it, no matter what the cost. Even if that cost is life-I didn't ask him whether he meant his or mineor else it must fall silent, which for me would be worse than death.

And then, Director, I felt a stab in my heart; a flash of light, a thunderbolt that shatters the darkness but also the spirit, because I realized what it was that he would immediately ask me and I knew that it was all over. The road impassable, the bridge collapsed, the abyss insurmountable. It seemed to me that I could already hear him asking me about the Home, and about you, Director, about the Foundation and about us and about what it's really like inside here and about how things, love, the world, really are. Naturally, because he too, Director, is convinced-like everyone, like me before I came here- that once you enter the Home you finally see the truth for what it is - no longer veiled, reflected and distorted, disguised and made-up as it is seen on the outside, but directly, face to face. Oh to sing the secret of life and death, he would say, who we are whence we come where we are going, but the perimeter is unyielding, the pen fractures against the bronze doors that conceal destiny, and so you're left outside to puzzle hopelessly over passing on and enduring, over yesterday today and tomorrow, and all you can do is put the pen in your mouth and suck on it, because only the great, horrific Truth is worthy of song-at least of his song, he didn't say it but he thought it—and that Truth can only be known behind those doors.

There outside, Director, people are yearning to know; even those who pretend they have no interest in knowing would give anything to know. He's yearning to know more than anybody, because he's a poet and poetry, he says, should uncover and tell the secret of life, tear away the veil, break down the doors, reach the bottom of the sea where the pearl is hidden. Maybe, I thought, he had primarily—only? — come to get me for this reason, to know, to question me, so that I might tell him what lies behind these doors and he could take up his lyre and extol a new, unprecedented song, a song that tells what no one else knows.

I could just see him, clinging to me, awaiting my every word, his green eyes feverish ... and how could I tell him that ... You see my point, Director. How could I tell him that here inside, apart from the light that is so much fainter, it's just the same as outside? That we are behind the mirror, but that the back is also a mirror, no different from the other. Here too 
objects deceive, dissembling and changing color like medusas. There are a great many of us, like outside; even more of us, which makes it all the more difficult to know one another. I've spoken with one or two, but nobody knows where he's from-oh sure, the city, his parents, even his grandparents, although their memory grows dim, but as for what he's seeking, the secret of his origin and end, nobody knows anything about that. We even form friendships, from time to time even a flirtation or maybe something more, a little fling, an affair, but here too it soon becomes impossible to tell the difference between one and the other and before long it's the same old story, mix-ups and misunderstandings. In next to no time you no longer know if you love each other or if it's just routine, and then all the rest, whining vindictiveness fits of pique, in short just like back home.

For that matter, why should we know more than those on the outside, more than we ourselves knew when we were out there? And you too, Director, why should we be able to see you here? We assume, as we used to assume, that there is someone running the whole shebang, but who he is and what he's like and how he is ... why should we know that? Those ailments and infirmities that sent us to these corridors and to these dark vales, those small calamities of the heart or brain, the venomous bane of a snake or a gas valve don't help us to better understand this immense labyrinth of before and after, of never and always and me and you and ...

We're on the other side of the mirror, but it's still a mirror, and all we see is a pallid face, without being certain whose it is. If someone breaks a leg, he doesn't expect to see the Director because of it, and racking one's brains isn't of any more help. The river flows, blood flows, a dike breaks, the water overflows and floods the fields, the swimmer goes under, sink or swim, re-emerges, goes on swimming without seeing anything, either in the blinding midday light or the dark of night.

Tell him that I, even here inside, know no more than he does? He would have had a stroke, that bard of mine. I could just picture his complaints, a man who was done for, a poet whose theme had been stolen from him; he would think that cosmic conspiracy was all a scheme against him, to break him, to condemn him to silence. If he told others that here inside it's just the same as outside, they would rip him to shreds, especially his fervent female admirers who worship him as a guru, and if he kept quiet about it he would feel like a coward. But most of all, how humiliating, to have come this far, all the way down here, only to find out that it wasn't worth it, that behind the door there is nothing to report.

I could just see him, harrowed dismayed panicky livid in a huff furious with me for having spoiled it all for him—and then the days and 
nights together, me at his side and him looking at me crooked, the pain in the ass who brought the curtain down on his stage, scared that I would blab it around to others, embarrassed to be seen with me, he who had departed for the unknown world like a hero and returned empty-handed. And when the time came, for him or for me, to return to the Home again, this time for good, what a farce having to repeat our goodbyes, now merely polite formalities. All of a sudden I felt exhausted, spent; the thought of starting all over again, cooking, washing, making love, going to the theatre, inviting people to dinner, thanking them for the flowers, talking, misunderstanding and misinterpreting one another, as always, sleeping getting up getting dressed ...

No, impossible, I couldn't have done it, I couldn't do it. I felt so tired all of a sudden. Still, perhaps I would have gritted my teeth and swallowed my fatigue and I would have carried on. Women can do that, they do it almost all the time, even when they no longer know why or for whom. Even the idea of having him always underfoot again didn't exactly ... but most of all the idea of having to keep quiet about it, changing the subject whenever he asked, whenever he wanted to know, given how sensitive, how fragile he is ...

So that's the reason, Director. No, it's not what people said, that he turned around out of extreme love, unable to be patient and wait, and therefore because of too little love. Nor was it because, had I gone back with him, to him, he would no longer have been able to sing those sweet, poignant songs that expressed the pain of losing me, of every loss, songs that had been around the world, distributed by juke boxes and later by CD's, loved by everyone, who would continue to love them only if he still sang them and others like them, his torment over my absence, the wind that moved the strings of his lyre, that made him a poet only if he was without me, for the ache of being without me.

I've heard that silly gossip. No, Director, it wasn't on account of such a pitiful, trite reason that he turned around and lost me. That's a false accusation spread by envious colleagues who want to depict him as a narcissistic egotist to make him lose favour with the public, maybe the same ones who spread those rumours about the pretty boys whom he supposedly consoled himself with in my absence, infuriating all those adoring female admirers of his, jealous enough to scratch his eyes out. No, Director. It was me. He wanted to know and I prevented him. God knows it cost me. Yes, it's true, I was tired, by now I had gotten used to the Home, almost fond of its routines. Still, I would have loved to go out for a little while-just for a little while, we both knew it—into that summer light—at least for 
one summer, a summer on that small island where he and I ... Even by myself, even without him I would have been happy to go walking there.

But I would have destroyed him, by going with him and answering his inevitable questions. Me, destroy him? I'd sooner be bitten by a serpent a hundred times more venomous than that tedious infection, rather than do that.

You will therefore understand, Director, why, when by then we were almost at the doors, I called to him in a strong, firm voice, the voice from when I was young, on the other side, and he-I knew he would not be able to resist - he turned around, as I felt myself being sucked back, lighter and lighter, a paper doll in the wind, a shadow that lengthens retreats and merges with the other shadows of the evening, and he watched me, petrified, but safe and sound, and I vanished joyfully from his view, because I could already see him returning to life tormented but strong, unaware of the void, still capable of serenity, perhaps even of happiness. Now in fact, at home, in our house, he is sleeping quietly. A little tired, of course, but ...

\section{Translator's Note}

The words "have mercy on this unhappy lover" are a distant echo of Giacomo Leopardi's "infelice amante" in the poem "Consalvo": "sostegno e cibo / Esser solea dell'infelice amante" (Leopardi, Canti, XVII), [had once been comfort / and sustenance for her unhappy lover] (from Canti: Poems. Trans. by Jonathan Galassi. New York: Farrar, Strauss and Giroux, 2010). The phrase "she knew that noisy life, adult, hostile, threatened our youth" is an indirect citation from Umberto Saba's poem "Caro luogo": "Vagammo tutto il pomeriggio in cerca / d'un luogo a fare di due vite una. / Rumorosa la vita, adulta, ostile, / minacciava la nostra giovinezza", [We wandered all afternoon in search / of a place to make two lives one. / Noisy life, adult, hostile, / threatened our youth] (from Songbook: The Selected Poems of Umberto Saba. Trans. by George Hochfield and Leonard Nathan, New Haven: Yale University Press, 2009). 